\title{
Subnormal Clusters in the Context of the Current COVID-19 Outbreak: Challenges for Brazilian Public Health
}

\author{
Samuel Cota Teixeira*
}

Institute of Biomedical Science, Department of Immunology, Federal University of Uberlândia, Uberlândia, MG, Brazil

\author{
Keywords \\ COVID-19, Subnormal Clusters, Favelas, Public Health
}

To the Editor,

The recent Coronavirus Disease 2019 (COVID-19) outbreak, caused by the Severe Acute Respiratory Syndrome Coronavirus 2 (SARS-CoV-2), has rapidly become a worldwide public health concern. On February 3, 2020, the Brazilian government declared the COVID-19 pandemic as a public health emergency; thus, the following question is raised: What is the current situation in the Brazilian subnormal clusters popularly known as favelas seven months later?

São Paulo and Rio de Janeiro are the most populous states in the Southeast region of Brazil, and have presented the highest rate of cases and deaths caused by COVID-19 in the last months (Table 1). On September 13, 2020, São Paulo accumulated 892,257 cases and 32,606 deaths; while Rio de Janeiro presented 242,491 cases and 16,990 deaths (Table 1 ). Despite the higher rates of cases and deaths presented by São Paulo when compared to Rio de Janeiro, to date, the mortality rate/100,000 inhabitants in the Rio de Janeiro is 98.4 when compared to São Paulo with 71.0 [1]. Therefore, the current situation in the Rio de Janeiro has become an emergency public health problem, where a large portion of the population resides in poor living conditions in typical favelas (Figure 1).

Brazil is a large country marked by a fragile health system that has failed to offer an equal access to the public health services, which is highlighted mainly in areas of social exclusion such as in the Brazilian favelas. Illustrating that, Pereira, et al. [2] has published an article addressing the potential risks of transmission of the recent Coronavirus Disease 2019 (COVID-19) in Brazilian favelas. The authors showed that the health inequalities, overcrowding population, pollution and the lack of basic sanitary conditions can contribute to the high risk of transmission of the novel coronavirus.

According to a survey carried out in the Rio de Janeiro's favelas, about $75.5 \%$ of people with COVID-19 symptoms did not seek medical care, and $10 \%$ of deaths occurred at home, without any medical assistance [3]. Adding another layer of complexity to the public health crisis in Rio de Janeiro, nurses and nursing technicians went on strike on July 23,2020 , after accumulating months of back wages [4].

Although $24 \%$ of the population of the city of Rio de Janeiro lives in about 1000 favelas, the Brazilian government has failed to collect the number of cases and deaths by COVID-19. Illustrating this, a recent study carried out in four Rio de Janeiro's favelas demonstrated that approximately 90,200 infected people never appeared on public panels [5]. In addition to underreporting cases, one of the most challenges for facing the COVID-19 outbreak in the favelas, the low number of deaths disclosed by official reports shows that the victims of this viral pandemic remain almost invisible to the health system [5]. Taken together, the underestimated reality faced by people living in these areas becomes a tremendous problem for the flexibilization process. As result, even without a real sense of the seriousness of the situation in the favelas, the Brazilian authorities have decided to open bars and restaurants, without taking into account the peculiarities of the poor conditions of the favelas to face the rapid spread of COVID-19 [6].

Due to the divergencies and lack of data disclosed by different levels of government, some non-governmental organizations together have proposed a "COVID-19-unifying panel in favelas" to consolidate more accurately the data on the cases and deaths caused by COVID-19 in the Rio de Janeiro's favelas $[6,7]$. On August 13, 2020, according to the COVID-19 panel were confirmed 9,641 cases and 1,415 deaths of fave-

*Corresponding author: Dr. Samuel Cota Teixeira, Ph.D, Institute of Biomedical Science, Federal University of Uberlândia, Campus Umuarama, Av. Para, 1720 | 38400239, Uberlândia-MG, Brazil, Tel: +55-34-32258569

Accepted: October 07, 2020

Published online: October 09, 2020

Citation: Teixeira SC (2020) Subnormal Clusters in the Context of the Current COVID-19 Outbreak: Challenges for Brazilian Public Health. Ann Public Health Reports 4(1):70-72 
Citation: Teixeira SC (2020) Subnormal Clusters in the Context of the Current COVID-19 Outbreak: Challenges for Brazilian Public Health. Ann Public Health Reports 4(1):70-72

Table 1: Number of cases and deaths caused by COVID-19 in the Brazilian states of São Paulo and Rio de Janeiro during the months of March to September (2020) [1].

\begin{tabular}{|l|l|l|l|l|}
\hline \multirow{2}{*}{ Date (2020) } & \multicolumn{2}{|c|}{ São Paulo } & \multicolumn{2}{c|}{ Rio de Janeiro } \\
\hline 03/March & Number of cases & Number of deaths & Number of cases & Number of deaths \\
\hline 03/April & 2 & 0 & 0 & 0 \\
\hline 03/May & 4,048 & 219 & 1,074 & 47 \\
\hline 03/June & 31,772 & 2,627 & 11,139 & 1,019 \\
\hline 03/July & 123,483 & 8,276 & 59,240 & 6,010 \\
\hline 03/August & 310,702 & 15,694 & 118,956 & 10,500 \\
\hline 07/September & 560,218 & 23,365 & 168,064 & 13,604 \\
\hline
\end{tabular}

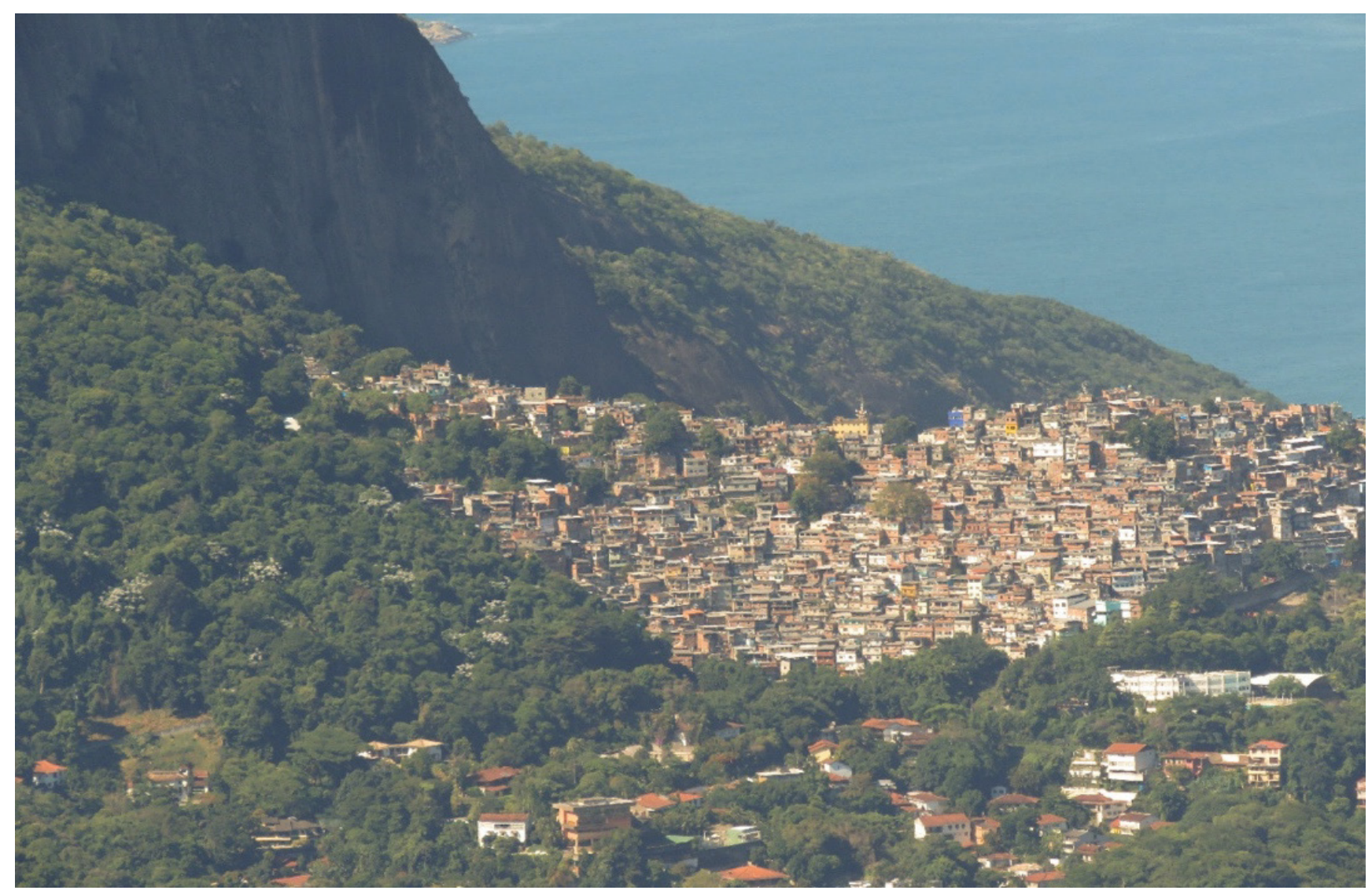

Figure 1: Typical favela surrounded by forest located at the base of a hill in the city of Rio de Janeiro, Brazil.

la residents. In addition, Table 2 shows the current numbers of cases and deaths caused by COVID-19 in the main Rio de Janeiro's favelas. Taken together, this panel aims to support preventive actions carried out by community movements, as well as to pressure the federal government to create public health policies to protect this vulnerable group, which has been marked by a historical neglect over generations by the public sector. Therefore, the fight against the current pandemic has been left to civil society [6].

After seven months that the current coronavirus pandemic has been declared a public health emergency by Brazil, to date, favela residents have yet to deal with a public system that has not offered minimal conditions to combat this viral disease. In Box 1, the main emergency problems and chal- lenges have faced by Brazilian favelas are highlighted. It is known that, to mitigate the rapid spread of COVID-19, multifactorial public health measures are required, such as mass testing, population awareness, isolation, social distance and contact tracking [8]. However, these measures are far from being a reality to be achieved for people living in the favelas. Thus, the bleak situation in Brazilian favelas raises concerns and leaves doubts about the ways of COVID-19in these places on the margins of public health services. Box 1 - Summarizes the current situation of Brazilian favelas in the context of the COVID-19 outbreak $[5,6,9]$.

\section{Conflicts of Interest}

The author declares no conflict of interest. 
Citation: Teixeira SC (2020) Subnormal Clusters in the Context of the Current COVID-19 Outbreak: Challenges for Brazilian Public Health. Ann Public Health Reports 4(1):70-72

Box 1: Summarizes the current situation of Brazilian favelas in the context of the COVID-19 outbreak [5,6,9].

- Lack of tests resulting in high lethality rates in favelas, where most people depend on the public health system.

- It takes about two weeks to schedule the exam and up to one month to receive the results.

- Underreporting in the number of cases and deaths masking the sad reality in the favelas.

- Divergencies between data disclosed by different levels of the Brazilian government, such as Ministry of Health, and State and Municipal Secretaries.

- Favela residents are plagued by fear of supply shortages.

- High rate of "community transmission", where it is practically impossible to trace the route of infection.

- $60 \%$ of Rio's favela youths have lost more than half of their income.

- $60 \%$ of the favela residents, who are not working or relying on donations, have income to stay for a maximum of one week.

- The low family income has forced the residents of the communities to leave to work, usually in regions far from their homes.

- Both non-governmental organizations and resident-led initiatives have taken responsibility for mitigating the coronavirus pandemic in the face of insufficient public policies.

Table 2: Number of accumulated cases and deaths caused by COVID-19 in the Rio de Janeiro's favelas with the highest transmission rate. The data were obtained from COVID-19-unifying panel in favelas with last update on September 14, 2020 [7].

\begin{tabular}{|l|l|l|}
\hline Rio de Janeiro's favelas & $\begin{array}{l}\text { Number of } \\
\text { cases }\end{array}$ & $\begin{array}{l}\text { Number of } \\
\text { deaths }\end{array}$ \\
\hline Complexo da Maré & 1,667 & 126 \\
\hline Comunidade do Engenho & 873 & 128 \\
\hline Comunidade Sem Terra & 553 & 189 \\
\hline Complexo da Penha & 538 & 43 \\
\hline Morro do Carvão & 532 & 126 \\
\hline Complexo do Jacaré & 493 & 53 \\
\hline Complexo do Alemão & 491 & 44 \\
\hline Comunidade de Chaperó & 487 & 85 \\
\hline Rocinha & 391 & 62 \\
\hline Vidigal & 356 & 19 \\
\hline Cidade de Deus & 347 & 65 \\
\hline
\end{tabular}

\section{Acknowledgments}

This study was supported by CNPq, CAPES, and FAPEMIG.

\section{References}

1. Brazilian ministry of health (2020) Coronavirus Brasil.

2. RJ Pereira, GNL do Nascimento, LHA Gratão, et al. (2020) The risk of COVID-19 transmission in favelas and slums in Brazil. Publ Health 183: 42-43.

3. SOS Favela! Rede solidária contra o Coronavírus (2020) Pesquisa sobre o COVID-19 nas favelas e periferias do estado do Rio de Janeiro.

4. G1 Rio de Janeiro (2020) Enfermeiros e técnicos terceirizados da Saúde do RJ entram em greve; funcionários fazem manifestação.

5. O GLOBO Rio (2020) Alta taxa de letalidade e números de casos inexplicavelmente baixos põem em dúvida dados da Covid-19 nas favelas do Rio.

6. Rio on watch - Relatos das favelas cariocas (2020) Lançamento do Painel Unificador Covid-19 Nas Favelas do Rio de Janeiro.

7. Painel Unificador das Favelas do Rio de Janeiro.

8. Yonghong X, Mili ET (2020) Taking the right measures to control COVID-19. Lancet Infect Dis 20: 523-524.

9. Instituto Locomotiva: Pesquisa \& Estratégia (2020) Pesquisa revela que mais da metade dos moradores das favelas não tem renda para mais de uma semana.

\section{Ethical Approval}

Not required.

DOI: $10.36959 / 856 / 496$

Copyright: (C) 2020 Teixeira SC. This is an open-access article distributed under the terms of the Creative Commons Attribution License, which permits unrestricted use, distribution, and reproduction in any medium, provided the original author and source are credited. 